\title{
Analisis Pebandingan Retur, Volume Perdagangan Saham dan Pengumuman Dividen pada Kinerja Perusahaan Indeks Saham LQ-45 pada tahun 2017
}

\author{
Erwan Iskandar
}

\begin{abstract}
Dosen Tetap Fakultas Ekonomi dan Bisnis Islam IAI Al- Azhaar Lubuklinggau
Erwaniska@yahoo.com
\end{abstract}

\begin{abstract}
Abstrak
Dividen merupakan salah satu bentuk informasi publik dalam pasar modal yang dianggap sebagai suatu signal dari perusahaan untuk menunjukkan kinerja dan prospek perusahaan di masa depan karena dividen merupakan salah satu informasi yang dapat mempengaruhi harga saham. Di Indonesia sejumlah perusahaan yang telah go public pembayaran dividen, merupakan cara klasik memberikan imbalan dalam bentuk pemberian aset keuangan (financial asset) perusahaan kepada para pemegang saham. Seperti halnya pengumuman dividen yang dilakukan oleh emiten yang tergabung dalam kinerja perusahaan indeks saham LQ-45. Dari pengumuman dividen tersebut melatar belakangi penelitian ini untuk menguji kandungan informasi dari pengumuman dividen.Adapun fokus penelitian ini adalah Untuk mengetahui perbandingan yang signifikan pada return saham sebelum dan sesudah pengumuman dividen. Untuk mengetahui perbandingan yang signifikan pada volume perdagangan saham sebelum dan sesudah pengumuman dividen. Dengan menggunakan metode purposive sampling dalam pengambilan sampel, dan menggunakan indikator Return dan Volume Perdagangan Saham, serta melalui uji paired sample T-test yang dibantu sistem komputerisasi program SPSS Versi 11.5 for windows. Hasil penelitian membuktikan bahwa tidak terdapat perbedaan yang signifikan pada return dan aktivitas volume perdagangan saham sebelum dan sesudah pengumuman dividen. Dalam penelitian ini dapat disimpulkan bahwa pengumuman dividen tidak mempunyai kandungan informasi yang mengakibatkan pasar tidak bereaksi terhadap pengumuman dividen tersebut.
\end{abstract}

Kata Kunci: Return, Volume Perdagangan Saham, Pengumuman Dividen. 


\section{A. Pendahuluan}

Sebagai instrumen ekonomi, pasar modal tidak terlepas dari berbagai pengaruh ekonomi. Adanya pengaruh tersebut akan mempengaruhi perubahan harga saham dari suatu emiten yang ada di pasar modal, seperti: kinerja perusahaan, perubahan strategi perusahaan, pengumuman laporan keuangan, laporan deviden perusahaan, dan pengumuman pendanaan yang berhubungan dengan pemecahan saham, pembelian saham, dan pengumuman joint venture (Jogiyanto, 2003: 373).

Perkembangan aktivitas pasar modal yang pesat ini membawa perubahan besar terhadap tuntunan kualitas informasi. Informasi ini sangat diperlukan oleh investor untuk mengurangi ketidakpastian dalam pengambilan keputusan. Dengan adanya informasi yang relevan dan yang dipublikasikan, maka hal ini dapat mempengaruhi harga-harga sekuritas yang ada di pasar modal. Pengujian terhadap kandungan informasi dimaksudkan untuk melihat reaksi pasar dari saat pengumuman jika pengumuman mengandung informasi maka diharapkan pasar akan bereaksi pada waktu pengumuman tersebut diterima pasar.

Salah satu informasi yang dapat mempengaruhi harga dari sekuritas yaitu adanya pengumuman dividen. Pada perusahaan yang telah go public pembayaran dividen, merupakan cara klasik memberikan imbalan dalam bentuk pemberian aset keuangan (financial asset) perusahaan kepada para pemegang saham. Dividen adalah bagian laba atau pendapatan perusahaan yang ditetapkan oleh direksi (dan disahkan oleh rapat pemegang saham) untuk dibagikan kepada pemegang saham (Halim, 2005: 21). Pembayarannya diatur berdasarkan ketentuan yang berlaku pada jenis saham yang ada. Dividen merupakan salah satu bentuk informasi publik dalam pasar modal yang dianggap sebagai suatu signal dari perusahaan untuk menunjukkan kinerja dan prospek perusahaan di masa depan. Apabila perusahaan meningkatkan pembayaran dividen, hal ini dapat ditafsirkan sebagai harapan manajemen akan membaiknya kinerja perusahaan di masa yang akan datang. Lebih jauh lagi, perusahaan membayar dividen untuk mendorong investor lain untuk membeli saham baru dengan harga yang lebih tinggi (Sawitri, 2007: 248). 
Beberapa kemungkinan dapat digunakan untuk mendeteksi apakah pasar secara individu merespon pengumuman dividen sebagai informasi untuk membuat keputusan investasi. Return saham merupakan ekspektasi yang diharapkan oleh investor (Jogiyanto, 2003: 433). Dimana dalam berinvestasi, ada kalanya seorang investor berharap adanya return saham yang besar. Sedangkan volume perdagangan merupakan suatu penjumlahan dari setiap transaksi yang terjadi di bursa saham pada waktu tertentu dan saham tertentu. Volume Perdagangan Saham merupakan merupakan salah satu faktor yang juga memberi pengaruh terhadap pergerakan saham. Zamroni (2003: 32) menyatakan bahwa "volume perdagangan merupakan unsur kunci dalam melakukan prediksi terhadap pergerakan harga saham".

Return, Volume perdagangan saham sebagai variabel indikator transaksi perdagangan efek di bursa efek yang dapat diamati dan diteliti untuk melihat reaksi pasar modal terhadap pengumuman dividen yang dilakukan oleh perusahaan yang sudah go public terutama pada indeks saham LQ-45. Indeks saham LQ-45 merupakan indeks yang hanya terdiri dari 45 saham yang telah dipilih melalui beberapa kriteria pemilihan sehingga akan terdiri dari sahamsaham yang liquiditas (liquid) tinggi dan juga mempertimbangkan kapitalisasi pasar saham tersebut. (Fakhruddin, $2001: 204$ )

\section{B. Rumusan Masalah}

1. Apakah terdapat perbedaan yang signifikan pada return saham sebelum dan sesudah pengumuman dividen?

2. Apakah terdapat perbedaan yang signifikan pada volume perdagangan saham sebelum dan sesudah pengumuman dividen?

\section{Metode Penelitian}

Penelitian ini merupakan penelitian yang menggunakan metode penelitian event study yaitu study yang mempelajari reaksi pasar terhadap suatu peristiwa (event) yang informasinya dipublikasikan sebagai suatu pengumuman. Event study dapat digunakan untuk menguji kandungan informasi (information content) dari suatu pengumuman (Jogiyanto, 2003: 411). 


\section{Pembahasaan dan Landasan Teori}

Return

Return saham merupakan ekspektasi yang diharapkan oleh investor (Jogiyanto, 2003: 433). Dimana dalam berinvestasi, ada kalanya seorang investor berharap adanya return saham yang besar. Karena itu merupakan timbal balik perusahaan terhadap investor tersebut dan merupakan suatu indikator perusahaan apakah peruahaan tersebut dapat dikatakan laba/rugi.

\section{Volume Perdagangan Saham}

Volume perdagangan merupakan suatu penjumlahan dari setiap transaksi yang terjadi di bursa saham pada waktu tertentu dan saham tertentu. Volume Perdagangan Saham merupakan merupakan salah satu faktor yang juga memberi pengaruh terhadap pergerakan saham. Zamroni (2003: 32) menyatakan bahwa "Volume perdagangan merupakan unsur kunci dalam melakukan prediksi terhadap pergerakan harga saham". Ia meyakini bahwa ketika volume perdagangan cenderung mengalami kenaikan saat harga turun, maka pasar diindikasikan dalam keadaan bearish. Sedangkan ketika volume perdagangan cenderung meningkat selama harga naik maka pasar diindikasikan dalam keadaan bullish, dan ketika volume cenderung mengalami penurunan selama harga mengalami kenaikan maka pasar dalam keadaan bearish.

\section{Dividen}

Dividen adalah bagian laba atau pendapatan perusahaan yang ditetapkan oleh direksi (dan disahkan oleh rapat pemegang saham) untuk dibagikan kepada pemegang saham (Halim, 2005: 21). Pembayarannya diatur berdasarkan ketentuan yang berlaku pada jenis saham yang ada.

Berikut ini merupakan prosedur pembagian dividen :
a. Tanggal pengumuman (declaration date)
b. Cum-dividend date
c. Ex-dividend date.
d. Tanggal pencatatan pemegang saham (recording date).
e. Tanggal pembayaran dividen (payment date) 
Faktor-faktor yang Mempengaruhi Kebijakan Dividen Kinerja Perusahaan Indeks Saham LQ-45

Dalam melakukan pembayaran dividen diperlukan beberapa pertimbangan yang harus dilakukan. Pertimbangan-pertimbangan tersebut harus disesuaikan dengan konsep teori pembayaran dividen dan penilaian perusahaan. Van Horne dan Machowich (1999: 501) menjelaskan faktor-faktor dalam yang dianalisis perusahaan dalam memutuskan kebijakan dividen, adalah :
a. Peraturan Hukum
b. Kebutuhan Pendanaan Perusahaan
c. Likuiditas
d. Kemampuan untuk Meminjam
e. Pengendalian

\section{Pengertian Indeks saham LQ-45}

Indeks ini terdiri dari 45 saham yang dipilih setelah melalui beberapa kriteria sehingga indeks ini terdiri dari saham-saham yang mempunyai likuiditas yang tinggi dan juga mempertimbangkan kapitalisasi pasar dari saham-saham tersebut. Untuk masuk dalam pemilihan tersebut, sebuah saham harus memenuhi kriteria sebagai berikut :

a. Masuk dalam top 60 dari total transaksi saham di pasar reguler (rata-rata nilai transaksi selama 12 bulan terakhir).

b. Masuk dalam ranking yang didasarkan pada nilai kapitalisasi pasar (ratarata kapitalisasi pasar selama 12 bulan terakhir).

c. Telah tercatat di BEI sekurang-kurangnya 3 bulan.

d. Memiliki kondisi keuangan perusahaan, prospek pertumbuhan perusahaan, frekuensi dan jumlah transaksi yang baik di pasar reguler. (Fakhruddin, $2001: 204)$

\section{Review Indeks dan Pergantian Saham}

Bursa Efek Jakarta terus memantau perkembangan komponen saham yang masuk dalam perhitungan Indeks LQ-45. Setiap tiga bulan sekali akan dilakukan review pergerakan rangking saham-saham yang akan digunakan dalam 
perhitungan Indeks LQ-45. Pergantian saham akan dilakukan dalam enam bulan sekali, yaitu setiap awal bulan februari dan agustus.

Apabila terdapat saham yang tidak memenuhi criteria lagi, maka saham tersebut harus dikeluarkan dari perhitungan indeks dan diganti dengan saham lain yang memenuhi kriteria. (Fakhruddin, 2001 : 205)

\section{Hari Dasar Indeks LQ-45}

Indeks LQ-45 dihitung mundur hingga tanggal 13 Juli 1994 sebagai hari dasar, dengan nilai dasar 100, sehingga memiliki data historis yang cukup panjang.

\section{Analisis Event Study}

\section{Return}

Dari hasil perhitungan tersebut di atas diperoleh nilai rata-rata return pada tahun 2017 sebelum pengumuman dividen menunjukkan nilai negatif yaitu sebesar $-0,0025$ dan nilai tersebut lebih rendah dibanding sesudah pengumuman dividen nilai rata-rata return sahamnya kembali mengalami peningkatan yaitu sebesar -0,0008. Nilai rata-rata return sebelum pengumuman dividen menunjukkan angka yang lebih kecil dibandingkan nilai setelah pengumuman dividen pada tahun 2017 dengan selisih sebesar 0,0017. Hal ini menunjukkan tidak adanya pengaruh yang signifikan dengan adanya pengumuman dividen terhadap return saham pada tahun 2017 dan mengindikasikan bahwa pasar tidak merespon pengumuman dividen karena pengumuman dividen tersebut dianggap sebagai bad news bagi para investor.

Sedangkan nilai rata-rata return pada tahun 2017 sebelum pengumuman dividen menunjukkan nilai positif yaitu sebesar 0,0016 dan nilai tersebut lebih tinggi dibanding sesudah pengumuman dividen nilai rata-rata return sahamnya mengalami penurunan yaitu sebesar -0,0033. Nilai rata-rata return sebelum pengumuman dividen menunjukkan angka yang lebih besar dibandingkan nilai sesudah pengumuman dividen pada tahun 2017 dengan selisih sebesar 0,0049. Hal ini menunjukkan adanya pengaruh yang signifikan dengan adanya pengumuman dividen terhadap return saham pada tahun 2017 dan 
mengindikasikan bahwa pasar merespon pengumuman dividen karena pengumuman dividen tersebut dianggap sebagai good news bagi para investor.

Dari menunjukkan bahwa return tertinggi pada tahun 2017 terjadi pada hari ke delapan setelah terjadinya peristiwa yaitu 0.0147 dan return terendah terletak pada saat terjadinya peristiwa yaitu sebesar -0,0241. Selama periode pengamatan sebelum dan sesudah pengumuman dividen terjadi fluktuasi return yang sangat tajam. Sedangkan return tertinggi pada tahun 2017 terjadi pada hari ke lima setelah terjadinya peristiwa yaitu 0.0295 dan return terendah terletak pada hari ke dua setelah terjadinya peristiwa yaitu sebesar -0,0204. Selama periode pengamatan sebelum dan sesudah pengumuman dividen terjadi fluktuasi return yang sangat tajam.

Berbeda pada tahun 2017 grafik tersebut dapat dilihat bahwa terjadi perbedaan fluktuasi yang sangat besar antara sebelum dan sesudah pengumuman dividen pada tahun 2017 terhadap nilai return karena para investor banyak melakukan transaksi pembelian saham dikarenakan investor terpengaruh secara positif akan pengumuman dividen pada tahun 2017 untuk mendapatkan dividen sehingga memperoleh nilai return yang lebih besar. Keadaan ini berbeda sesudah pengumuman dividen karena pergerakan rata-rata return relatif kecil dan pasar tidak begitu tertarik untuk membeli saham melainkan lebih tertarik untuk menjual saham karena jangka waktu pembagian dividen masih cukup lama. Kondisi tersebut disebut dengan Ex-dividend date merupakan tanggal dimana perdagangan saham sudah tidak mengandung hak untuk mendapatkan dividen. Apabila para investor tetap membeli saham pada tanggal ini maka investor tidak akan memperoleh pembagian dividen. Pada saat Ex-dividend date harga-harga saham akan cenderung mengalami penurunan akan tetapi investor lebih banyak untuk melakukan penjualan saham.

\section{Aktivitas Volume Perdagangan}

Pengukuran aktivitas volume perdagangan saham merupakan suatu instrumen yang dapat digunakan untuk melihat reaksi pasar modal terhadap suatu informasi dengan parameter pergerakan aktivitas volume perdagangan. Atau dengan kata lain, aktivitas volume perdagangan mengambarkan sentimen pasar 
disamping juga menggambarkan fluktuasi harga saham dan bisa mengetahui kondisi saham semakin likuid atau tidak.

Tingginya nilai aktivitas volume perdagangan sebelum pengumuman dividen menunjukkan bahwa pengumuman dividen saham mengalami berpengaruh positif terhadap investor. Sehingga para investor lebih banyak untuk melakukan pembelian saham di bursa. Berikut ini rata-rata volume perdagangan saham harian selama dua puluh satu hari. Karena peristiwanya merupakan peristiwa yang nilai ekonomisnya dapat ditentukan dengan mudah oleh investor (Jogianto, 2003: 436).

\section{Uji Statistik Dengan Menggunakan Paired Sample T-Test}

\section{Return}

Dari hasil pengujian uji paired sample t test dapat diketahui bahwa average return pada sebelum dan sesudah pengumuman dividen pada tahun 20117 terdapat hasil yang tidak signifikan. Pada saat sebelum dan sesudah pengumuman dividen nilai signifikansi sebesar 0.754 (tidak signifikan). Hal ini dikarenakan investor tidak merespon adanya pengumuman dividen saham pada tahun 2017.

Dari hasil pengujian uji paired sample t test dapat diketahui bahwa average return pada sebelum dan sesudah pengumuman dividen pada tahun 2017 terdapat hasil yang tidak signifikan. Pada saat pada saat sebelum dan sesudah dividen nilai signifikansi sebesar 0.240 ( tidak signifikan). Hal ini dikarenakan investor tidak merespon adanya pengumuman dividen saham pada tahun 2017.

\section{Volume Perdagangan Saham}

Dari hasil pengujian uji paired sample $t$ test dapat diketahui bahwa rata-rata volume perdagangan saham pada sebelum dan sesudah pengumuman dividen pada tahun 2017 terdapat hasil yang tidak signifikan. Pada saat sebelum dan sesudah dividen nilai signifikansi sebesar 0.38 ( tidak signifikan). Hal ini dikarenakan investor tidak merespon adanya pengumuman dividen saham pada tahun 2017. 
Dari hasil pengujian uji paired sample t test dapat diketahui bahwa ratarata volume perdagangan saham pada sebelum dan sesudah pengumuman dividen pada tahun 2017 terdapat hasil yang tidak signifikan. Pada saat sebelum dan sesudah dividen nilai signifikansi sebesar 0.281 (tidak signifikan). Hal ini dikarenakan investor tidak merespon adanya pengumuman dividen saham pada tahun 2017.

\section{E. Kesimpulan dan Saran}

\section{Kesimpulan}

Berdasarkan hasil penelitian dan pembahasan dapat di ambil kesimpulan yakni sebagai berikut:

1. Adanya pengumuman deviden tidak mempunyai perbedaan yang signifikan terhadap return sebelum dan sesudah pengumuman deviden. Dari hasil pengujian statistik menggunakan SPSS for windows versi 11.5 dengan uji Paired Sample T Test diperoleh hasil bahwa sebelum dan sesudah pengumuman dividen tidak terdapat perbedaan yang signifikan. Dari hasil tersebut mengindikasikan bahwa pengumuman dividen tidak mempunyai kandungan informasi yang mengakibatkan pasar tidak bereaksi atas pengumuman tersebut atau dapat diartikan bahwa tidak adanya perbedaan yang signifikan dengan adanya pengumuman dividen tersebut terhadap return saham.

2. Adanya pengumuman deviden tidak mempunyai perbedaan yang signifikan terhadap volume perdagangan saham sebelum dan sesudah pengumuman dividen. Dari hasil pengujian statistik menggunakan SPSS for windows versi 11.5 dengan uji Paired Sample T Test diperoleh hasil bahwa sebelum dan sesudah pengumuman deviden tidak terdapat perbedaan yang signifikan.

\section{Saran}

1. Bagi investor

Dari hasil pengujian dan analisis yang dilakukan menunjukkan bahwa pengumuman dividen kurang mempunyai kandungan informsi sehingga diharap semua investor atau calon investor mencari atau mendapatkan 
informasi dari perusahaan agar tidak terjadi asimetris informasi dalam pengambilan keputusan investasi.

2. Bagi Emiten

Dari hasil pengujian dan analisis mengindikasikan bahwa dalam pengumuman dividen kurang mempengaruhi preferensi investor atau perusahaan (emiten) dalam melakukan pengumuman dividen kurang mampu memenuhi tujuan dividen yaitu meningkatkan likuiditas saham. Sehingga diharapkan juga dapat memberikan informasi tentang prospek yang baik dan bertumbuh agar informasi yang disampaikan direspon positif oleh investor.

\section{DAFTAR PUSTAKA}

Fakhruddin dan Hadianto, Sopian, 2001. Perangkat Dan Model Analisis Investasi Di Pasar Modal. Penerbit PT. Elex Media Komputindo, Jakarta.

Halim, Abdul, 2005. Analisis Investasi. Penerbit Salemba Empat, Jakarta.

Husnan, Suad, 1998. Dasar-dasar Teori Portofolio dan Analisis Sekuritas. Edisi Ketiga, Cetakan Kedua, Penerbit UPP-AMP YKPN, Yogyakarta.

Jogiyanto, 2003. Teori Portofolio dan Analisis Investasi. Edisi Ketiga, Penerbit BPFE, Yogyakarta.

Sawitri, 2007. Studi Empiris Reaksi Pasar Terhadap Publikasi Pembayaran Deviden. Jurnal Keuangan dan Perbankan, Tahun XI (2): 248-259

Van Horne, James C dan, John M Machowich. 1999. Prinsip - prinsip Manajemen Keuangan. Alih Bahasa Oleh Tim Penerjemah Salemba Empat, Jakarta.

Zamroni, Ahmad. 2003. Analisis Reaksi Pasar Modal Indonesia Terhadap Peristiwa Peledakan BOM Bali 12 Oktober 2002 (Pengamatan terhadap Return, Abnormal Return, Trading Volume Activity, dan Security Return Variability Saham). Skripsi tidak diterbitkan. Malang: Fakultas Ekonomi Universitas Negeri Malang. 